\title{
QUEEN'S
UNIVERSITY
BELFAST
}

\section{Thiol and Cardiovascular risk factor status in a male Northern Irish population}

Edgar, K. S., Woodside, J., Skidmore, P., Farrell, K., Cardwell, C., McKinley, M., Young, I., Whitehead, A. S., Gey, K. F., Yarnell, J., \& Evans, A. (2008). Thiol and Cardiovascular risk factor status in a male Northern Irish population. International journal for vitamin and nutrition research. Internationale Zeitschrift für Vitamin- und Ernährungsforschung. Journal international de vitaminologie et de nutrition, 78(4-5), 208-216.

\section{Published in:}

International journal for vitamin and nutrition research. Internationale Zeitschrift für Vitamin- und

Ernährungsforschung. Journal international de vitaminologie et de nutrition

\section{Queen's University Belfast - Research Portal:}

Link to publication record in Queen's University Belfast Research Portal

\section{General rights}

Copyright for the publications made accessible via the Queen's University Belfast Research Portal is retained by the author(s) and / or other copyright owners and it is a condition of accessing these publications that users recognise and abide by the legal requirements associated with these rights.

Take down policy

The Research Portal is Queen's institutional repository that provides access to Queen's research output. Every effort has been made to ensure that content in the Research Portal does not infringe any person's rights, or applicable UK laws. If you discover content in the Research Portal that you believe breaches copyright or violates any law, please contact openaccess@qub.ac.uk. 


\title{
Thiol and Cardiovascular Risk Factor Status in a Male Northern Irish Population
}

Kevin S. Edgar1, Jayne V. Woodside1, Paula Skidmore², Christopher Cardwell, Kathryn Farrell', Michelle C. McKinley', Ian S. Young ${ }^{1}$, Alexander S. Whitehead ${ }^{3}$, K. Fred Gey ${ }^{4}$, John W.G. Yarnell ${ }^{1}$ and Alun Evans ${ }^{1}$

1 Centre for Clinical and Population Science, School of Medicine and Dentistry, Queen's University Belfast, Grosvenor Road, Belfast BT12 6BJ, Northern Ireland 2 School of Medicine, Health Policy and Practice, University of East Anglia, Norwich, NR4 7JT 3.Department of Pharmacology and Center for Pharmacogenetics, University of Pennsylvania School of Medicine, Philadelphia, PA 19104, USA

${ }^{4}$ Department of Biochemistry, University of Berne, Switzerland, Fax: \#442890235900,E-mail: j.woodside@qub.ac.uk

Received for publication: November 22, 2007; Accepted for publication: August 4, 2008

\begin{abstract}
Objectives: Raised plasma homocysteine is a risk factor for cardiovascular disease (CVD). Cysteine has also been associated with CVD risk. In this study; we investigated the association between known CVD risk factors, dietary factors, and total plasma cysteine, cysteinyl-glycine, and homocysteine.

Methods: The study group was 765 male workers aged between $30-49$ years. The dietary habits of the subjects were recorded using a food frequency questionnaire. Body mass index (BMI), smoking status, and blood pressure were assessed, and fasting blood samples were taken for analysis of serum concentrations of vitamins, lipids, total plasma cysteine, cysteinyl-glycine, and homocysteine, and genotyping for the methylenetetrahydrofolate reductase (MTHFR) polymorphism.

Results: In multivariable analyses, cysteine was significantly positively associated with age and negatively associated with serum vitamin $B_{12}$ and serum vitamin $B_{6}$, while cysteinyl-glycine was significantly positively associated with BMI. Homocysteine (tHcy) was significantly negatively associated with serum folate, serum vi$\operatorname{tamin} B_{12}$, and fruit and vegetable intake, and also depended on the MTHFR $677 \mathrm{C}>\mathrm{T}$ genotype.

Conclusions: Our data show a significant relationship between age, serum levels of B-vitamins and cysteine, and BMI and cysteinyl-glycine. In agreement with other studies, we also confirm an association between tHcy, serum folate and vitamin $B_{12}$, MTHFR genotype, and fruit and vegetable intake. Further investigation into the role of these thiols and their determinants in CVD is required.
\end{abstract}

Key words: Thiols, homocysteine, B vitamins, cardiovascular risk factors, MTHFR 


\section{Introduction}

High total plasma homocysteine (tHcy) concentration (hyperhomocysteinemia) is an independent risk factor for cardiovascular disease (CVD) $[1,2]$. Cysteine $\left(\mathrm{C}_{3} \mathrm{H}_{7} \mathrm{NO}_{2} \mathrm{~S}\right)$ is another sulfhydryl-containing amino acid that is structurally similar to homocysteine. The body can chemically transform homocysteine to cysteine via the trans-sulfuration pathway in a two-step process catalyzed by two vitamin $B_{6}$-dependent enzymes, cystathionine $\beta$-synthase and cystathionase. The association between total plasma cysteine (tCys) and CVD has not been investigated to the same extent as tHcy, however, some studies have shown raised tCys in patients with vascular diseases [3-6], although not all studies have demonstrated this association $[7,8]$. Total cysteinyl-glycine ( 1 Cys-gly) has not been studied in relation to CVD risk, but is metabolically linked to tHcy and tCys, with which it can be quantified in the same chromatography assay [9]. Alterations in thiol status have been observed in a range of other diseases, including preeclampsia [10], rheumatoid arthritis [11], type 2 diabetes [12], and end-stage renal disease [13].

CVD is a major public health issue in Northem Ireland. tCys and tHcy appear to be indicators of risk, yet, apart from serum $B$ vitamins and thcy, little is known about the association between plasma thiol status, nutritional status and intake, and other CVD risk factors. It has been suggested that the association between elevated $\mathrm{tHcy}$ and CVD risk is indirectly mediated through classic CVD risk factors such as smoking and hypertension [14, 15] (i.e. that hyperhomocysteinemia is a risk marker rather than a risk factor). In this study the associations between thiol concentrations, dietary intake and serum B-vitamins, and CVD risk factors were investigated.

\section{Subjects and Methods}

The study was approved by the Research Ethics Committee of the Faculty of Medicine, Queen's University Belfast.

\section{Subjects and clinic procedure}

Participants were male volunteers aged $30-49$ years employed by a single, large, Belfast-based company and included all grades of staff (i.e. manual, clerical, administrative, and executive). Employees within the correct age group, identified by the company Occupational Health Unit, were contacted by letter. Approximately $40 \%$ responded $(n=765)$ and they were asked to attend the $O c$ cupational Health Unit clinic at $7.30 \mathrm{am}$. Each subject signed a consent form after receiving an information sheet which explained the purpose of the research, the examination they would undergo, and emphasized that results would be kept confidential. They were asked to complete a previously validated food frequency questionnaire (FFQ) [16]. The questionnaire was checked and, if required, assistance given in its completion by a nutritionist; a brief medical history was taken, and height and weight were measured. Demographic data and smoking status (smoker or non-smoker; time since stopping smoking; number of cigarettes smoked per day) were recorded. Blood pressure swas recorded using a Spengler automated sphygmomanometer on the right arm and a fasting venous blood sample was then taken from the left arm. An EDTA-treated sample was used to provide plasma for tHcy, tCys, and tCys-gly analysis and a clotted sample provided serum for vitamin analysis. Plasma was separated from the EDTA blood samples within 15 minutes of venipuncture at $4^{\circ} \mathrm{C}$, while the serum samples were kept in the dark and returned to the laboratory for processing. Samples were aliquotted as required. All samples were stored at $-80^{\circ} \mathrm{C}$ until analysis. Samples were collected between November 1994 and May 1995, and all sample analysis was completed by May 1997.

\section{Blood measurements}

TCys, tCys-gly, and tHcy (both free and protein-bound) were assayed by high-performance liquid chromatography (HPLC) according to the method of Ubbink et al [9]. Concentrations of serum cobalamin and serum folate were measured by a competitive protein binding method using a SimulTRAC-S radioassay kit (ICN Pharmaceuticals, California, USA). Pyridoxal-5-phosphate (PLP) concentrations in serum were quantified using an HPLC method by Reynolds \& Brain [17]. Serum total cholesterol was estimated using an enzymatic CHOD-PAP kit, while serum triglycerides were measured using the Peridochrom GPOPAP kit (both Boehringer Mannheim). Precipitation for high-density lipoprotein (HDL)-cholesterol estimation employed phosphotungstic $\mathrm{Mg}^{2+}$ reagents [18]. All cholesterol assays were carried out on the Cobas Fara autoanalyzer. Low-density lipoprotein (LDL)-cholesterol was estimated using the Friedewald formula:

LDL cholesterol $(\mathrm{mmol} / \mathrm{L})=$ total cholesterol $-\mathrm{HDL}$ cholesterol $-0.45 \times$ triglyceride.

Methylenetetrahydrofolate reductase (MTHFR) $677 \mathrm{C}$ $>\mathrm{T}$ genotypes were determined according to the method of Frosst et al [19] and have previously been reported [20].

Mean daily energy and nutrient intakes for each subject were calculated from the FFQ using a specialist software package (Q Builder, Tinuviel Software, Warrington).

Int. J. Vitam. Nutr. Res., 78 (4/5), 2008, - Hogrefe \& Huber Publishers 


\section{Statistical methods}

Triglyceride, homocysteine, serum folate, serum cobalamin, and serum pyroxidal phosphate (PLP) were not normally distributed so these were logarithmically transformed. The associations between continuous variables were examined using Pearson correlation coefficients. Comparisons between two groups were made using the Student's independent samples $t$-test. Where necessary, a version of the test appropriate when variances of the samples were unequal was used [21]. For the comparison of more than two groups, for example to test for the effects of MTHFR genotype on thiol concentrations, an one-way ANOVA was used, followed by the Newman-Keuls multiple range comparison test [21]. Multivariable analysis was carried out using general linear modeling. All statistical analyses were performed using SPSS for Windows, version 14.0

\section{Results}

The population descriptive data is presented in Table I. Mean body mass index (BMI) was $26.1 \mathrm{~kg} / \mathrm{m}^{2}$ showing that $63.7 \%$ of the study population was overweight (BMI $\geq 25 \mathrm{~kg} / \mathrm{m}^{2}$ ), with $10.6 \%$ being obese (BMI $\left.>30 \mathrm{~kg} / \mathrm{m}^{2}\right)$. The mean systolic and diastolic blood pressures (128/80
$\mathrm{mmHg}$ ) were in the normal range. The mean total plasma cholesterol was $5.83 \mathrm{mmol} / \mathrm{L}$, which is above.recommended levels [22]. The dietary intake questionnaire showed that the mean daily intake of fruit and vegetables ( 2.6 portions) was well below the recommended five portions per day.

The association of thiols with each other and with recognized CVD risk factors is shown in Table II. Cysteine was significantly positively associated with tCys-gly, tHcy, and age. tCys-gly was significantly positively associated with $\mathrm{tCys}$, tHcy, systolic and diastolic blood pressure, and BMI. tHcy was only positively associated with tCys and tCys-gly, and was negatively associated with fruit and vegetable intake.

Associations between thiols and serum B-vitamins and intake are also presented (Table II). tCys was significantly negatively associated with serum vitamin $B_{12}$ and serum $B_{6}$, whilst tHcy was significantly negatively associated with serum folate and $B_{12}$. The only thiol to be associated with B-vitamin intake was tHcy, which was significantly negatively associated with folate and vitamin $B_{6}$ intake.

The association between thiol status and categorical CVD risk factors is shown in Table III. Thiols did not differ by smoking status or whether subjects carried out shift work or not (used as a marker of manual/non-manual status). tCys-gly and tCys did not depend on coffee consumption. However tHcy tended to be higher in those who consumed more than 4 cups of coffee per day compared

Table I: Population descriptive data

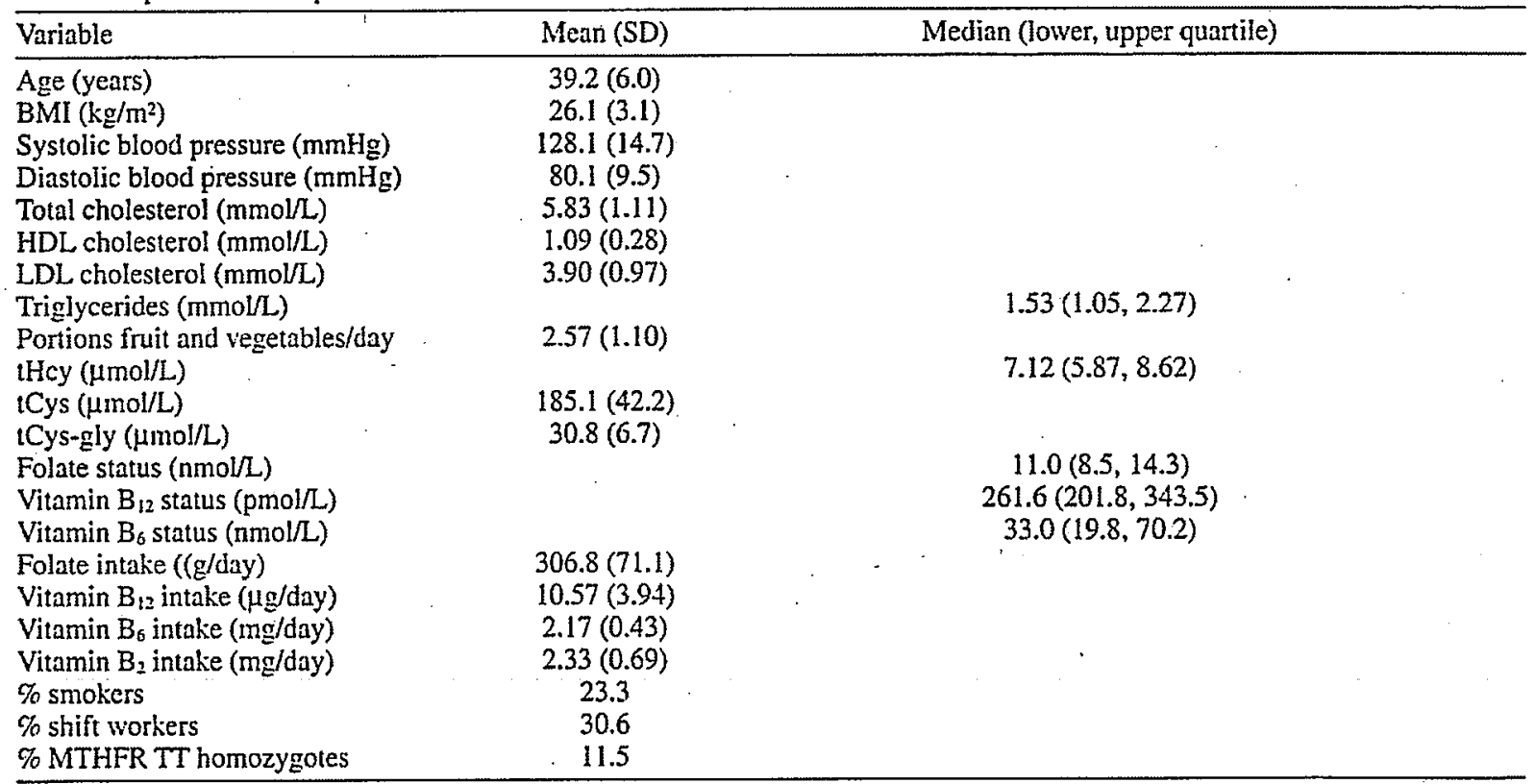

Continuous data presented as mean (SD) except for triglyceride, $t$ Hcy, folate, $\mathrm{B}_{12}$, and $\mathrm{B}_{6}$ status, where data presented as median (lower quartile, upper quartile).

Int. J. Vitam. Nutr. Res., 78 (4/5), 2008, 을 Hogrefe \& Huber Publishers 
Table II: Associations between thiols, cardiovascular risk factors and B-vitamin status and intake

\begin{tabular}{|c|c|c|c|}
\hline. & $\begin{array}{c}\text { tCys } \\
(\mu \mathrm{mol} / \mathrm{L})\end{array}$ & $\begin{array}{l}\text { tCys-gly } \\
(\mu \mathrm{mol} / \mathrm{L})\end{array}$ & $\begin{array}{c}\mathrm{tHcy} \\
(\mu \mathrm{mol} / \mathrm{L})\end{array}$ \\
\hline $\begin{array}{l}\text { tCys }(\mu \mathrm{mol} / \mathrm{L}) \\
\text { tCys-gly }(\mu \mathrm{mol} / \mathrm{L}) \\
\text { tHcy }(\mu \mathrm{mol} / \mathrm{L})\end{array}$ & $\begin{array}{c}1 \\
0.405 * *(<0.001) \\
0.345 *(<0.001)\end{array}$ & $\begin{array}{c}0.405 * * 0.001) \\
1 \\
0.264 * * 0.001)\end{array}$ & $\begin{array}{c}0.345 * *(<0.001) \\
0.264 * *(<0.001) \\
1\end{array}$ \\
\hline $\begin{array}{l}\text { Age (years) } \\
\text { BMI (kg/m²) } \\
\text { Systolic BP (mmHg) } \\
\text { Diastolic BP (mmHg) } \\
\text { Total cholesterol (mmol/L) } \\
\text { HDL (mmol/L) } \\
\text { LDL (mmol/L) } \\
\text { Triglycerides (mnol/L) } \\
\text { Fruit and vegetable intake (portions/day) } \\
\text { Folate status (nmol/L) } \\
\text { B }_{12} \text { status (pmol/L) } \\
\text { B }_{6} \text { status (nmol/L) } \\
\text { Folate intake ( } \mu \text { g/day) } \\
\text { B }_{12} \text { intake ( } \mu \text { g/day) } \\
\text { B }_{6} \text { intake (mg/day) } \\
\text { B }_{2} \text { intake (mg/day) }\end{array}$ & $\begin{array}{c}0.114 * *(<0.01) \\
0.070(0.08) \\
0.002(0.96) \\
0.048(0.23) \\
0.057(0.16) \\
0.049(0.22) \\
0.056(0.17) \\
0.006(0.87) \\
-0.017(0.66) \\
0.066(0.10) \\
-0.092 *(0.02) \\
-0.101 *(0.02) \\
0.015(0.72) \\
-0.032(0.42) \\
0.013(0.74) \\
-0.017(0.68)\end{array}$ & $\begin{array}{c}-0.018(0.66) \\
0.109 * *(<0.01) \\
0.081 *(0.04) \\
0.109 * *(<0.01) \\
0.051(0.20) \\
-0.022(0.58) \\
0.024(0.55) \\
0.077(0.05) \\
-0.003(0.94) \\
0.044(0.28) \\
-0.057(0.16) \\
0.025(0.56) \\
0.013(0.76) \\
-0.022(0.58) \\
-0.023(0.57) \\
0.010(0.80)\end{array}$ & $\begin{array}{c}0.069(0.09) \\
-0.016(0.69) \\
0.042(0.30) \\
0.078(0.05) \\
0.001(0.97) \\
0.032(0.43) \\
0.032(0.42) \\
-0.062(0.12) \\
-0.090 *(0.025) \\
-0.446 *(<0.001) \\
-0.377 *(<0.001) \\
0.040(0.35) \\
-0.115 * *(<0.01) \\
-0.037(0.35) \\
-0.127 *(<0.01) \\
-0.066(0.10)\end{array}$ \\
\hline
\end{tabular}

Data presented as Pearson correlation coefficient (p-value). Triglycerides, tHcy and folate, vitamin $B_{12}$ and vitamin $B_{6}$ status were logarithmically transformed. ${ }^{*} p<0.05 ; * * p<0.01$. Data presented on $n_{\max }=765$ subjects.

Table III: Categorical cardiovascular risk factor status, MTHFR status, and thiol status

\begin{tabular}{|c|c|c|c|}
\hline Variable & $\begin{array}{l}\text { tCys } \\
(\mu \mathrm{mol} / \mathrm{L})\end{array}$ & $\begin{array}{l}\text { tCys-gly } \\
(\mu \mathrm{mol} / \mathrm{L})\end{array}$ & $\begin{array}{l}\text { tHcy } \\
(\mu \mathrm{mol} / \mathrm{L})\end{array}$ \\
\hline $\begin{array}{l}\text { Smoking } \\
\text { Yes }(n=161) \\
\text { No }(n=462)\end{array}$ & $\begin{array}{l}184.9(42.3) \\
185.0(42.3) \\
P=0.97\end{array}$ & $\begin{array}{l}30.5(6.8) \\
30.9(6.7) \\
P=0.47\end{array}$ & $\begin{array}{l}7.26(6.06,8.55) \\
7.17(5.85,8.68) \\
p=0.68\end{array}$ \\
\hline $\begin{array}{l}\text { Shift work } \\
\text { Yes }(\mathrm{n}=192) \\
\text { No }(\mathrm{n}=428)\end{array}$ & $\begin{array}{l}189.5(45.1) \\
183.0(40.9) \\
P=0.07\end{array}$ & $\begin{array}{l}31.2(6.8) \\
30.7(6.7) \\
P=0.41\end{array}$ & $\begin{array}{l}7.20(5.86,8.70) \\
7.20(5.87,8.59) \\
P=1.00\end{array}$ \\
\hline $\begin{array}{l}\text { Coffee consumption/day } \\
<=4 \text { cups }(\pi=554) \\
>4 \text { cups }(\mathrm{n}=67)\end{array}$ & $\begin{array}{l}185.0(42.9) \\
184.8(37.2) \\
\mathrm{P}=0.97\end{array}$ & $\begin{array}{l}30.8(6.9) \\
30.7(5.7) \\
P=0.92\end{array}$ & $\begin{array}{l}7.13(5.84,8.54) \\
7.72(6.15,9.00) \\
P=0.08\end{array}$ \\
\hline $\begin{array}{l}\text { MTHFR genotype } \\
+1+(n=72) \\
+1-(n=273) \\
-1-(n=280)\end{array}$ & $\begin{array}{l}182.9(40.7) \\
185.6(41.4) \\
185.2(43.5) \\
P=0.89\end{array}$ & $\begin{array}{l}30.4(6.7) \\
30.9(6.7) \\
30.9(6.8) \\
P=0.83\end{array}$ & $\begin{array}{l}9.46^{z}(6.65,12.18) \\
7.12^{b}(5.89,8.64) \\
6.77^{b}(5.75,8.05) \\
P<0.001\end{array}$ \\
\hline
\end{tabular}

Data presented as mean (SD) except for tHcy, presented as geometric mean (IQ range). Two group comparisons were made using Students' independent samples $i$-tests, whilst the three genotypes were compared using one way ANOVA with Student-NewmanKeuls post-hoc comparison tests. ${ }^{*} \mathrm{p}<0.001$ for difference between genotypes, superscript letters show homogeneous subsets.

to those who drank $\leq 4$ cups of coffee per day, although this did not reach statistical significance $(p=0.08)$.

Table III also shows the association between MTHFR $677 \mathrm{C}>\mathrm{T}$ genotype and thiol status. In univariate analyses, MTHFR 677TT homozygotes did not have altered
tCys or tCys-gly concentrations but; as previously reported [18] did have relatively high tHcy concentrations.

The variables described above in univariate analyses were entered into three separate multivariable regression models with $t C y s, t C y s-g l y$, and tHcy as the outcome vari-

Int. J. Vitan. Nutr. Res., 78 (4/5), 2008, (- Hogrefe \& Huber. Publishers 
Table IV: Multivariate regression modeling of thiol status

a) Cysteine

Average increase in $\mathrm{tCys}(\mu \mathrm{mol} / \mathrm{L})$ per unit increase

Crude $(95 \% \mathrm{Cl})$

Age (years)

BMI $\left(\mathrm{kg} / \mathrm{m}^{2}\right)$

$0.82(0.26,1.38)^{*}$

$0.9(-0.1,2.0)$

Vitamin $B_{12}^{2}$

$-8.9(-16.6,-1.2)^{*}$

$-4.3(-7.7,-0.8)^{*}$ Adjusted $195 \% \mathrm{Cl})$

Model contains age, $B M I$, vitamin $B_{12}$, and vitamin $B_{6}$ status.

2On the log scale.

* Significant at $5 \%$ level.

b) Cysteinyl-glycine

$0.62(0.02,1.21)^{*}$
$1.0(-0.1,2.0)$
$-9.0(-16.9,-1.1)^{*}$
$-3.9(-7.4,-0.5)^{*}$

\begin{tabular}{lcc} 
& \multicolumn{2}{c}{ Average increase in tCys-gly $(\mu \mathrm{mol} / \mathrm{L})$ per unit increase } \\
& Crude $(95 \% \mathrm{CI})$ & Adjusted $(95 \% \mathrm{CI})$ \\
\hline Age (years) & $-0.02(-0.11,0.07)$ & $-0.03(-0.12,0.06)$ \\
BMI $\left(\mathrm{kg} / \mathrm{m}^{2}\right)$ & $0.24(0.07,0.40)^{*}$ & $0.2(0.02,0.38)^{*}$ \\
Systolic BP $(\mathrm{mmHg})$ & $0.04(0.001,0.07)^{*}$ & $0.02(-0.02,0.06)$
\end{tabular}

Model contains age, BMI, and systolic blood pressure.

*Significant at $5 \%$ level.

c) Homocysteine

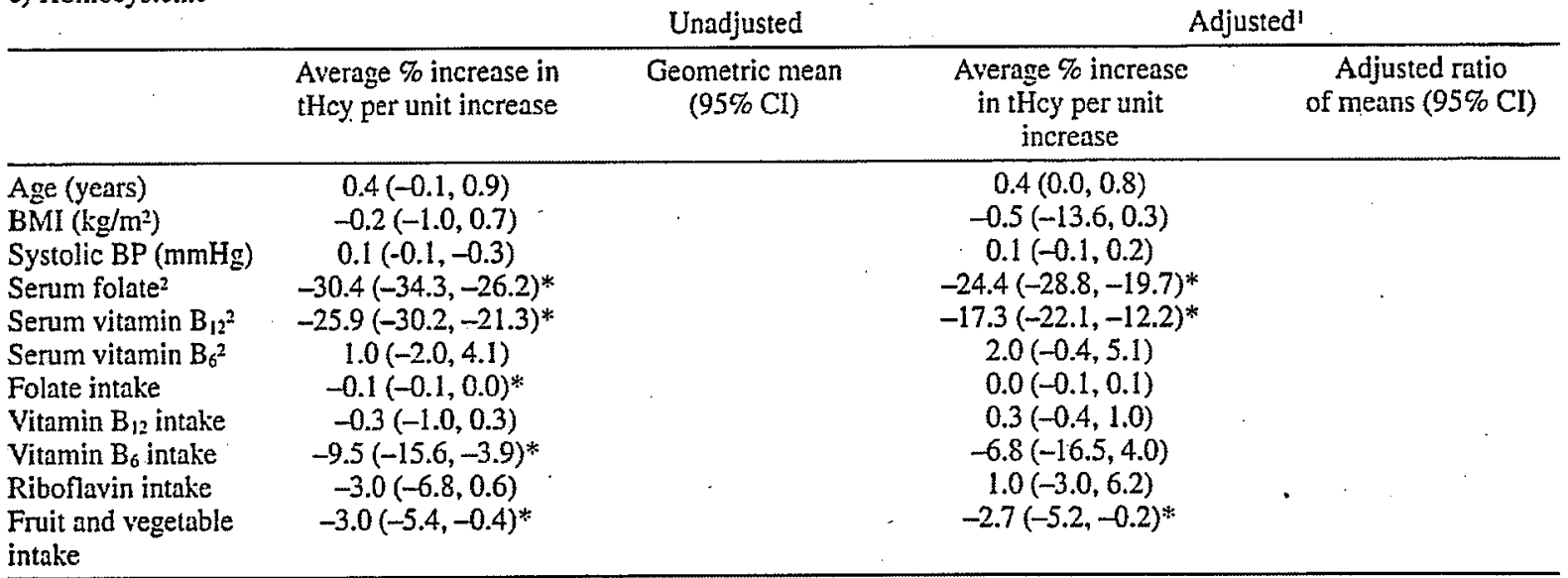

intake

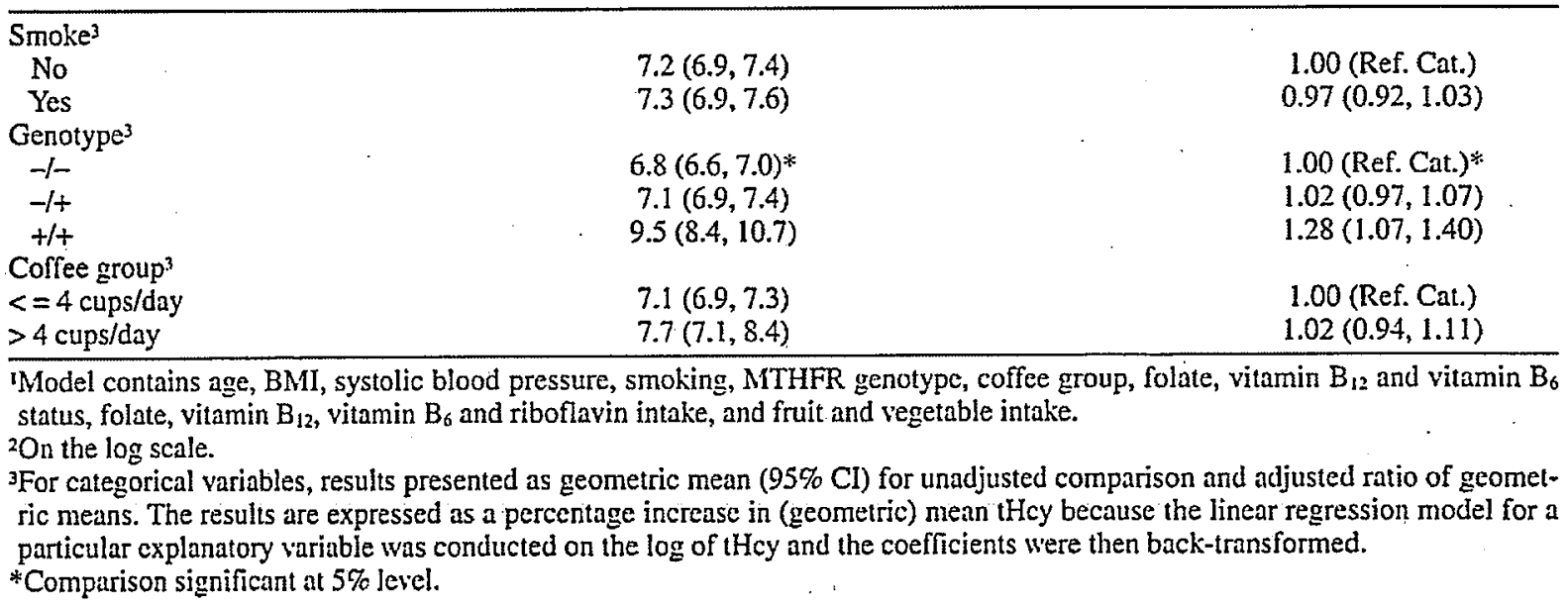

Int. J. Vitam. Nutr. Res., 78 (4/5), 2008, (1 Hogrefe \& Huber Publishers 
ables; age, BMI, any other significant factors from the univariate analysis, and other variables proposed to be associated with these thiols in previous studies, served as putative explanatory variables (Table IV).

There was a significant increase in $\mathrm{tCys}$ of $0.8 \mu \mathrm{mol} / \mathrm{L}$ per year of age $(p=0.004)$. After adjustment for other explanatory variables this was attenuated to $0.6 \mu \mathrm{mol} / \mathrm{L}$ but remained statistically significant $(p=0.04)$. For every unit increase in serum vitamin $B_{12}$ (on the In scale) there was a significant adjusted reduction in tCys of $9.0 \mu \mathrm{mol} / \mathrm{L}$, and for serum vitamin $\mathrm{B}_{6}$ (also on the $\ln$ scale) a significant adjusted reduction in tCys of $3.9 \mu \mathrm{mol} / \mathrm{L}$.

Each unit increase of BMI elevated tCys-gly by 0.24 $\mu \mathrm{mol} / \mathrm{L}$, an effect that remained statistically significant ( $\mathrm{p}$ $=0.03$ ) when attenuated to $0.2 \mu \mathrm{mol} / \mathrm{L}$ after adjustment for other explanatory variables. In contrast, a $0.04 \mu \mathrm{mol} / \mathrm{L}$ elevation in 1Cys-gly for each unit increase in systolic blood pressure was attenuated and lost significance after adjustment for other explanatory variables.

The main significant continuous variables associated with tHcy concentration after adjustment for other explanatory variables were serum folate (reduction of $\mathrm{tHcy}$ by $24.4 \%$ for every unit increase in folate on the in scale), serum vitamin $B_{12}$ (reduction of $t$ Hcy by $17.3 \%$ for every unit increase in vitamin $B_{12}$ on the $\ln$ scale), and fruit and vegetable intake (reduction of tHcy by $2.7 \%$ per daily portion of fruit and vegetables). MTHFR $677 \mathrm{C}>\mathrm{T}$ genotype was the only categorical variable associated with tHcy after adjustment, with the adjusted ratio of geometric means being 1.02 (95\% CI 0.97, 1.07) for CT heterozygotes compared to CC homozygotes, and 1.28 (95\% CI 1.07, 1.40) for TT homozygotes compared to CC homozygotes.

The addition of other variables to the model for each dependent variable (lipids, dietary intake of B-vitamins, serum B-vitamins, fruit and vegetable intake, blood pressure, MTHFR $677 \mathrm{C}>\mathrm{T}$ genotype, smoking, and coffee consumption) did not markedly affect the results. The maximum proportion of variation explained for the models described were $7 \%, 4 \%$, and $34 \%$ for tCys, tCys-gly, and $\mathrm{tHcy}$ respectively.

\section{Discussion}

In this study we investigated the plasma thiol status of 765 healthy men aged $30-49$ years, and examined how dietary factors including B-vitamin intake and serum B-vitamins, together with recognized CVD risk factors, were related to thiol status.

\section{Associations between thiols}

In univariate analysis the three thiols ( $\mathrm{tHcy}, \mathrm{tCys}$, and tCys-gly) were significantly associated with one another.
This is consistent with their close metabolic connection and in agreement with a number of other cross-sectional studies. In a study of 922 young people aged $4-18$ years, Bates et al [23], showed that tHcy was strongly and directly correlated with both tCys and $\mathrm{tCys-gly,} \mathrm{although} \mathrm{r}-$ values were not given for the associations, and in an earlier study of approximately $1600040-$ to 67 -year-old men and women, El-Khairy et al [24] showed an association between tHcy and tCys.

\section{Thiol status and recognized CVD risk factors}

In multivariate models, only age was found to be significantly associated with tCys; similarly, only BMI was significantly associated with tCys-gly status. Our findings differ from those of El-Khairy et al [24], who found BMI to be strongly associated with tCys, but not with tHcy. Increasing age has previously been associated with relatively higher concentrations of both $\mathrm{tCys}$ and $\mathrm{tHcy}$ [24-26]. A possible explanation for increased tCys levels is an agedependent decrease in enzyme activity involved in cysteine and homocysteine metabolism [27], or a reduction in renal function, as thiols have been shown to be elevated in renal disease [28]. Previous studies have also found a link between elevated tHcy and age $[29,30]$. The lack of finding of a significant increase in tHcy with increasing age seen in our study may have been due to the relative youth and narrow age range of the subjects (30-49 years), and have arisen previously as a possible consequence of increased atherosclerotic burden in more elderly subjects. Indeed, the El-Khairy study [24] included subjects aged $40-67$ years, who are likely to have had significant atherosclerotic disease.

Several large population studies have shown smokers to have higher tHcy than non-smokers [14, 24, 31, 32], although smaller studies, in agreement with this work, have found no such difference between smokers and non-smokers in tCys or tHcy $[24,26,33-34]$. Reasons for the discrepancy in results may simply be due to study size, or related to smoking prevalence or dose in these particular populations.

Although El-Khairy et al [24] found BMI to be strongly associated with tCys, no study to our knowledge has previously shown an association between $\mathrm{BMI}$ and tCysgly. However, a recent cross-sectional study in metabolic syndrome patients has shown that patients with individual components of the metabolic syndrome, including increased waist-to-hip ratio, have higher concentrations of gamma glutamyltransferase activity (GGT) and also higher levels of tCys-gly (and tCys) [35]. The action of GGT on glutathione results in its cleavage to tCys and tCys-gly, therefore GGT regulates their circulating concentrations. Our observed association between BMI and tCys-gly may therefore be linked through an increase in GGT. This

Int. J. Vitam. Nutr. Res., 78 (4/5), 2008, (1) Hogrefe \& Huber Publishers 
would need to be confirmed through assessment of circulating GGT concentrations, and this analysis was not performed in the current study.

A number of other factors may have affected the demonstrated associations, but were not available for inclusion in these annlyses. A number of observational studies have suggested an association between moderate alcohol consumption and tHcy concentrations [32, 36], whilst both renal function (as assessed by serum creatinine) has been shown to affect tHcy, and thiols in general $[28,37]$. Inclusion of these factors in our model may have altered the observed associations, and must be accepted as a weakness of these analyses.

\section{Thiols and serum $B$-vitamins and intake}

Inverse relationships were observed between tCys and both serum vitamin $B_{12}$ and $B_{6}$, and between tHcy and both serum folate and $B_{12}$ in univariate analyses, and remained significant in multivariate analyses.

Although many studies have shown an association between tHcy and B-vitamin intake and serum B-vitamins [38], few other studies have examined whether other thiols are associated with serum B-vitamins. Bates et al. did not show an association between tCys and $\mathrm{tCys}$-gly and B-vitamins in 4- to 18-year-old subjects or those over 65 , El-Khairy et al did not show an association between these two thiols and B-vitamin intake, and Midttun et al. found no relationship between serum PLP and tCys concentrations $[23,24,39]$. In this study, we observed an independent inverse association between $t C y s$ and plasma $B_{6}$ and $B_{12}$. A higher concentration of vitamin $B_{12}$ may lead to reduced tCys due to improved tHcy remethylation. In contrast to the inverse relationship observed in this study, other studies have found no relationship between PLP and tCys concentration $[23,24,39,40]$, however we were unable to adjust for serum creatinine in this study. A higher concentration of vitamin $B_{6}$ might be expected to lead to increased trans-sulfuration and so increased $\mathrm{tCys}$, however, PLP-dependent enzymes are involved in the catabolism as well as the formation of cysteine $[41,42]$. It is possible that a higher vitamin $B_{6}$ status leads to increased formation of cysteine but also increased catabolism. More research is needed to fully elucidate the effects of vitamin $\mathrm{B}_{6}$ status on cysteine metabolism.

Folate and $\mathrm{B}_{6}$ intake were significantly inversely associated with tHcy stalus in univariate analyses, but this relationship lost significance after multivariate adjustment. In contrast, fruit and vegetable intake, which also was inversely associated with tHcy concentrations, remained significant in the adjusted model. The latter is in accord with olher studies $[43,44]$, and it has been proposed that plasma folate is a biomarker of fruit and vegetable consumption [45]. In addition, two intervention studies have shown that increasing fruit and vegetable consumption lowers thcy concentrations $[46,47]$.

\section{MTHFR genotype and thiol status}

In both uni- and multivariate analyses, MTHFR $677 \mathrm{C}>\mathrm{T}$ genotype was only associated with tHcy status, and this has been reported previously for this data set [20]. A number of other studies have examined MTHFR 677C > T genotype in relation to $\mathrm{tCys}$ status in renal patients, but to our knowledge similar analyses have not previously been undertaken in healthy volunteers. Kimura et al [48] reported that the MTHFR TT genotype was associated with low tCys levels in hemodialysis patients, although this is contrary to what might be expected from a knowledge of the metabolic pathway. In contrast, Marcucci et al [49] did not report any difference in tCys status by MTHFR $677 \mathrm{C}$ $>$ T genotype in renal transplant recipients.

In conclusion, this study has shown that in this relatively young, healthy Northern Irish population, $t C y s$ increases with increasing age, whilst tCys-gly increases with increasing BMI. Apart from these findings, significant relationships between either tCys or tHcy and other CVD risk factors were not observed. As expected, significant associations were observed between tHcy and both serum $B$ vitamins and $M T H F R$ 677C $>T$ genotype and $t H c y$. Independent associations were also demonstrated in multivariate analyses between tCys and both serum vitamin $B_{12}$ and $B_{6}$, and between tHcy and fruit and vegetable intake. Overall the explanatory variables jentified in this study accounted for a modest amount of tCys and tCys-gly variation ( $7 \%$ and $4 \%$, respectively), and a relatively large proportion of tHcy variation (34\%). There has been extensive investigation of the role of tHcy in CVD but little concerning tCys. Due to their biochemical similarities and metabolic connections, further studies of tHcy and tCys in larger groups are needed to confirm the above results and, in particular, to further evaluate the suggested association of 1 Cys with the development of CVD.

\section{Acknowledgments}

We acknowledge the technical assistance of Caroline Mercer, Janet Lightbody, Trevor Linton, and Drew Mcllveen. Also the clinic nurses, Maureen McCourt and Geraldine O'Reilly, Kellie Byrne (nutritional assistant) and Ishbel McMillan (administration co-ordinator). Grateful thanks to Dr. Jenkinson of Shorts Brothers, plc., Belfast. This work was partly funded by NIH grants AR47663 and ES013508. 


\section{References}

1. Wald, D. S., Law, M. and Morris, J. K. (2002) Homocysteine and cardiovascular disease: Evidence on causality from a meta-analysis. BMJ 325, 1202.

2. Homocysteine Studies Collaboration. (2002) Homocysteine and risk of ischemic heart disease and stroke: A meta-analysis. JAMA 288, 2015.

3. Araki, A., Sako, Y., Fukushima, Y., Matsumoto, M., Asada, T. and Kita, T. (1989) Plasma sulfhydryl-containing amino acids in patients with cerebral infarction and in hypertensive subjects. Atherosclerosis 79, 139.

4. Mansoor, M.A., Bergmark, C., Svardal,A. M., Lonning, P.E. and Ueland, P.M. (1995) Redox status and protein binding of plasma homocysteine and other aminothiols in patients with early-onset peripheral vascular discase. Homocysteine and peripheral vascular disease. Arterioscler. Thromb. Vase. Biol. 15, 232.

5. Mills, B.J., Weiss, M.M., Lang, C. A., Liu, M.C. andZiegler, C. (2000) Blood glutathione and cysteine changes in cardiovascular disease. J. Lab. Clin. Med. 135, 396.

6. El-Khairy, L., Ueland, P.M., Refsum, H., Graham, I.M., Vollset, S.E. and European ConcertedAction Project. (2001) Plasma total cysteine as a risk factor for vascular disease: The European Concerted Action Project. Circulation 103, 2544.

7. van den Brandhof, W.E., Haks, K., Schouten, E. G. and Verhoef, P. (2001) The relation between plasma cysteine, plasma homocysteine and coronary atherosclerosis. Atherosclerosis 157,403 .

8. El-Khairy, L., Vollset, S.E., Refsum, H. and Ueland, P.M. (2003) Plasma total cysteine, mortality, and cardiovascular disease hospitalizations: the Hordaland Homocysteine Study. Clin. Chem. 49, 895.

9. Ubbink, J.B., Hayward Vermaak, W.J. and Bissbort, S. (1991) Rapid high:performance liquid chromatographic assay for total homocysteine levels in human serum. J. Chromatogr. 565,441 .

10. Raijmakers, M.T., Roes, E.M., Zusterzeel, P.L., Steegers, E. A. and Peters, W.H. (2004) Thiol status and antioxidant capacity in women with a history of severe pre-eclampsia. Br. J. Obstet. Gynaecol. 111, 207.

11. Giustarini, D., Lorenzini, S., Rossi, R., Chindamo, D., Di Simplicio, P. and Marcolongo, R. (2005) Altered thiol pattem in plasma of subjects affected by rheumatoid arthritis. Clin. Exp. Rheumatol. 23, 205.

12. Duman, B.S., Ozturk, M., Yilmazeri, S. and Hatemi, H. (2003) Thiols, malonaldehyde and total antioxidant status in the Turkish patients with type 2 diabetes mellitus. Tohoku J. Exp. Med. 201, 147.

13. Suliman, M.E., Stenvinkel, P., Heimburger, O., Barany, P., Lindholm, B. and Bergstrom, J. (2002) Plasma sulfur amino acids in relation to cardiovascular disease, nutritional status, and diabetes mellitus in patients with chronic renal failure at start of dialysis therapy. Am. J. Kidney Diseases 40, 480.

14. Troughton, J. A., Woodside, J. V., Young, I. S., Arveiler, D., Amouyel, P., Ferricres, J., Ducimetiere, P., Patterson, C.C., Kee, F., Yarnell, J.W., Evans, A. and PRIME Study Group.
(2007) Homocysteine and coronary heart disease risk in the PRIME study. Atherosclerosis 191, 90.

15. Graham, I.M., Daly, L. E., Refsum, H.M., Robinson, K., Brattstrom, L.E., Ueland, P.M., Palma-Reis, R.J., Boers, G. H., Sheahan, R.G., Israelsson, B., Uiterwal, C. S., Meleady, R., McMaster, D., Verhoef, P., Witteman, J., Rubba, P., Bellet, H. Wautrecht, J.C., de Valk, H.W., Sales Luis, A. C., Panot-Rouland, F.M., Tan, K. S., Higgins, 1., Garcon, D. and Andria, G. (1997) Plasma homocysteine as a risk factor for yascular disease. The European Concerted Action Project. JAMA 277, 1775.

16. Yamell, J. W., Fehily, A.M., Milbank, J.E., Sweetnam, P.M. and Walker, C.L. (1983) A short dietary questionnaire for use in an epidemiological survey: Comparison with weighed dietary records. Human Nutr. Applied Nutr. 37, 103.

17. Reynolds, T.M. and Brain, A. (1992) A simple internallystandardised isocratic HPLC assay for vitamin $B_{6}$ in human serum. J. Liquid Chromatogr. 15, 897.

18. Lopes-Virella, M.F., Stone, P., Ellis, S. and Colwell, J. A. (1977) Cholesterol determination in high-density lipoproteins separated by three different methods. Clin. Chem. 23, 882.

19. Frosst, P., Blom, H.J., Milos, R., Goyette,P., Sheppard, C.A., Matthews, R.G., Boers, G.J., den Heijer, M., Kluijtmans, L.A. and van den Heuvel, L.P. (1995) A candidate genetic risk factor for vascular disease: A common mutation in methylenetetrahydrofolate reductase. Nature Genetics 10, 111.

20. Harmon, D. L., Woodside, J. V., Yarnell, J. W., McMaster, D., Young, I.S., McCrum, E. E., Gey, K. F., Whitchead, A.S. and Evans, A.E. (1996) The common 'thermolabile' variant of methylene tetrahydrofolate reductase is a major determinant of mild hyperhomocysteinaemia. Q. J. Med. 89, 571.

21. Armitage, P. and Berry, G. (1994) Statistical methods in medical research. Blackwell Scientific Publications, Oxford.

22. British Cardiac Society, British Hypertension Society, Diabetes UK, HEART UK, Primary Care Cardiovascular Society, and Stroke Association. (2005) JBS 2: Joint British Societies' Guidelines on prevention of cardiovascular disease in clinical practice. Heart 91 Suppl 5, 1.

23. Bates, C.J., Mansoor, M.A., Gregory, J., Pentiev, K. and Prentice, A. (2002) Correlates of plasma homocysteine, cysteine and cysteinyl-glycine in respondents in the British $\mathrm{Na}$ tional Diet and Nutrition Survey of young people aged 4-18 years, and a comparison with the survey of people aged 65 years and over. British J. Nutr. 87, 71.

24. El-Khairy, L., Ueland, P.M., Nygard, O., Refsum, H. and Vollset, S.E. (1999) Lifestyle and cardiovascular disease risk factors as determinants of total cysteine in plasma: The Hordaland Homocysteine Study. Am. J. Clin. Nutr. 70, 1016.

25. van den Brandhof, W.E., Haks, K., Schouten, E.G. and Verhoef, P. (2001) The relation between plasma cystcine, plasma homocysteine and coronary atherosclerosis. Atherosclerosis $157,403$.

26. Ozkan, Y., Ozkan, E. and Simsek, B. (2002) Plasma total homocysteine and cysteine levels as cardiovascular risk factors in coronary heart disease. Int. J. Cardiol. 82, 269.

27. Nordstrom, M. and Kjellstrom, T. (1992) Age dependency of cystathionine beta-synthase activity in human fibroblasts

Int. J. Vitam. Nutr. Res., 78 (4/5), 2008, ( Hogrefe \& Huber Publishers 
in homocyst(e)inemia and atherosclerotic vascular disense. Atherosclerosis 94, 213 .

28. Wilcken, D.E.L. and Gupta, V.J. (1979) Sulphur containing amino acids in chronic renal failure with particular reference to homocysteine and cysteine-homocysteine mixed disulphide. Eur. J. Clin. Invest. 9, 301.

29. Boushey, C.J., Beresford, S.A., Omenn, G.S. and Motulsky, A.G. (1995) A quantitative assessment of plasma homocysteine as a risk factor for vascular disease. Probable benefits of increasing folic acid intakes. JAMA 274, 1049.

30. Eikelboom, J.W., Lonn, E., Genest, J., Jr., Hankey, G. and Yusuf, S. (1999) Homocyst(e)ine and cardiovascular disease: A critical review of the epidemiologic evidence. Annals Intern. Med. 131, 363.

31. Nygard, O., Voliset, S.E., Refsum, H., Stenswold, I., Tverdal, A., Nordrehaug, J.E., Ueland, M. and Kvale, G. (1995) Total plasma homocysteine and cardiovascular risk profile. The Hordaland Homocysteine Study. JAMA 274, 1526.

32. Jacques, P.F., Bostom, A. G., Wilson, P. W., Rosenberg I. H. and Selhub, J. (2001) Determinants of plasma total homocysteine concentration in the Framingham Offspring cohort. Am. J. Clin. Nutr. 73, 613.

33. Pancharuniti, N., Lewis, C. A., Sauberlich, H.E., Perkins, L.L., Go, R.C., Alvarez, J.O., Macaluso, M., Acton, R.T., Copeland, R.B. and Cousins, A.L. (1994) Plasma homocyst(e)ine, folate, and vitamin $B_{12}$ concentrations and risk for early-onset coronary artery disease. Am. J. Clin. Nutr. 59,940 .

34. Bergmark, C., Mansoor, M.A., Svardal, A. and de Faire, U. (1997) Redox status of plasma homocysteine and related aminothiols in smoking and nonsmoking young adults. Clin. Chem. 43, 1997.

35. Giral, P., Jacob, N., Dourmap, C., Hansel, B., Carrie, A., Bruckert, E., Girerd, X. and Chapman, M.J. (2008) Elevated gamma-glutanyltransferase activity and perturbed thiol profile are associated with features of the metabolic syndrome. Arterioscler. Thromb. Vasc. Biol. 28, 587.

36. Giles, W.H., Kittner, S.J., Croft, J. B. et al (1999) Distribution and correlates of elevated total homocysteine: the Stroke Prevention in Young Women Study. Ann. Epidemiol. 9, 307.

37. Refsum, H., Smith, A.D., Ueland, P.M., Nexo, E., Clarke, R., McPartlin, J., Johnston, C., Engbaek, F., Schneede, J., McPartlin, C. and Scott, J.M. (2004) Facts and recommendations about total homocysteine determinations: an expert opinion. Clin. Chem. 50, 3-32.

38. Strain, J.J., Dowey, L., Ward, M., Pentieva, K. and McNulty, H. (2004) B-vitamins, homocysteine metabolism and CVD. Proc. Nutr. Soc. 63, 597.

39. Midttun, Ø., Hustad, S., Schnecde, J., Vollset, S.E. and Ueland, P.M. (2007) Plasma vitamin B-6 forms and their relation to transsulfuration metabolites in a large, populationbased study. Am. J. Clin. Nutr. 86, 131.

40. Davis, S.R., Quinlivan, E.P., Stacpoole, P.W. and Gregory, J.F. $3^{\text {rs }}$ (2006) Plasma glutathione and cystathionine concentrations are elevated but cysteine flux is unchanged by dietary vitamin B-6 restriction in young men and women. J. Nutr. 136, 373.
41. Sturman, J.A. and Cohen, P. A. (1971) Cysteine metabolism in vitamin $B_{6}$ deficiency: evidence of multiple taurine pools. Biochem. Med. 5, 245.

42. Yamaguchi, K., Shigehisa, S., Sakakibara, S., Hosokawa, Y. and Ueda, 1. (1975) Cysteine metabolism in vivo of vitamin B6-deficient rats. Biochim. Biophys. Acta 38, 1.

43. Gao, X., Bermudez, O.I. and Tucker, K.L. (2004) Plasma $\mathrm{C}$-reactive protein and homocysteine concentrations are related to frequent fruit and vegetable intake in Hispanic and non-Hispanic white elders. J. Nutr. 134, 913.

44. Ganji, V., and Kafai, M.R. (2004) Frequent consumption of milk, yogurt, cold breakfast cereals, peppers, and cruciferous vegetables and intakes of dietary folate and riboflavin but not vitamins $B_{12}$ and $B_{6}$ are inversely associated with serum total homocysteine concentrations in the US population. Am. J. Clin. Nutr. 80, 1500.

45. Brevik, A., Vollset, S.E., Tell, G.S., Refsum, H., Ueland, P.M., Loeken, E. B., Drevon, C. A. and Andersen, L. F. (2005) Plasma concentration of folate as a biomarker for the intake of fruit and vegetables: The Hordaland Homocysteine Study. Am. J. Clin. Nutr. 81, 434.

46. Broekmans, W.M., Klopping-Ketelaars, I.A., Schuurman, C.R., Verhagen, H., van den Berg, H., Kok, F.J. and van Poppel, G. (2000) Fruits and vegetables increase plasma carotenoids and vitamins and decrease homocysteine in humans. J. Nutr. 130, 1578.

47. Samman, S., Sivarajah, G., Man, J. C., Ahmad, Z.I., Petocz, P. and Caterson, I.D. (2003) A mixed fruit and vegetable concentrate increases plasma antioxidant vitamins and folate and lowers plasma homocysteine in men. J. Nutr. 33, 2188.

48. Kimura, H., Gejyo, F., Suzuki, S., Takeda, T., Miyazaki, R. and Yoshida, H. (2000) A C677T mutation in the melhylenetetrahydrofolate reductase gene modifies serum cysteine in dialysis patients. Am. J. Kidney Diseases 36, 925.

49. Marcucci, R., Fedi, S., Brunelli, T., Pepe, G., Prisco, D., Rosati, A., Zanazzi, M., Bertoni, E., Abbate, R. and Salvadori, $M$. (2001) High cysteine levels in renal transplant recipients: Relationship. with hyperhomocysteinemia and 5,10-MTHFR polymorphism. Transplantation 71, 746 .

\section{Dr Jayne Woodside}

Nutrition and Metabolism Group

Centre for Clinical and Population Science

Lower Ground Floor, Pathology Building

Grosyenor Road

Belfast, BT12 6BJ

Northern Ireland, UK

Phone: +442890632585

Fax: +442890235900

E-mail: j.woodside@qub.ac.uk

Int. J. Vitam. Nutr. Res., 78 (4/5), 2008, (1) Hogrefe \& Huber Publishers 